DOI: https://doi.org/10.34069/AI/2021.48.12.12

How to Cite:

Kovalenko, E.G., Akimova, Y.A., Lebedev, A.V., \& Pinkovetskaia, I.S. (2021). Development of municipal areas in republic Mordovia. Amazonia Investiga, 10(48), 107-116. https://doi.org/10.34069/AI/2021.48.12.12

\title{
Development of municipal areas in republic Mordovia
}

\section{Развитие муниципальных районов республики Мордовия}

Received: November 4, 2021

Accepted: December 27, 2021

\author{
Written by: \\ E.G. Kovalenko $0^{40}$ \\ https://orcid.org/0000-0003-4688-6030 \\ Y.A. Akimova ${ }^{41}$ \\ https://orcid.org/0000-0002-0404-5105 \\ A.V. Lebedev ${ }^{42}$ \\ https://orcid.org/0000-0002-1927-5595 \\ I.S. Pinkovetskaia ${ }^{43}$ \\ https://orcid.org/0000-0002-8224-9031
}

\begin{abstract}
The purpose of the study is to assess the indicators for 2018 that characterize the levels of economic development of municipal districts of the Republic of Mordovia. The study was based on the modeling of socio-economic indicators using normal distribution functions. An assessment of relative indicators for 22 municipal districts was carried out. Three groups of municipal districts were formed using cluster analysis. It is proposed to use inclusive models for the effective development of municipal districts. Our research has shown that there is differentiation according to the most important indicators, therefore, further development of the considered areas will significantly improve the quality and standard of living in rural areas, as well as increase the investment potential of such territories and attractiveness for living and agricultural development.
\end{abstract}

Keywords: municipal areas, sustainable development, inequality, inclusive development, economic growth.

\begin{abstract}
Аннотация
Целью исследования является оценка показателей за 2018 год, характеризующих уровни экономического развития муниципальных районов Республики Мордовия. Исследование основывалось на моделировании социально-экономических показателей с использованием функций нормального распределения. Проведена оценка относительных показателей по 22 муниципальным районам. C помощью кластерного анализа сформированы три группы муниципальных районов. Предлагается использовать инклюзивные модели для эффективного развития муниципальных районов. Наше исследование показало, что существует дифференциация по наиболее важным показателям, поэтому дальнейшее развитие рассматриваемых районов позволит значительно улучшить качество и уровень жизни в сельской местности, а также повысить инвестиционный потенциал таких территорий и привлекательность для проживания и развития сельского хозяйства.
\end{abstract}

Ключевые слова: муниципальные районы, устойчивое развитие, неравенство, инклюзивное развитие, экономический рост.

\footnotetext{
${ }^{40}$ State and Municipal Management Department, N.P. Ogarev Mordovia State University, Saransk, Russia.

${ }^{41}$ State and Municipal Management Department, N.P. Ogarev Mordovia State University, Saransk, Russia.

${ }^{42}$ English Language for Professional Communication Department, N.P. Ogarev Mordovia State University, Saransk, Russia.

${ }^{43}$ Economic Analysis and State Management Department, Ulyanovsk State University, Ulyanovsk, Russia.
} 


\section{Introduction}

In the twenty-first century, much attention is paid to theoretical and practical issues of the development of municipal (rural) areas. The relevance of the question under consideration is due to the fact that both the developed and developing economies increase the role of municipal self-government; the efficiency of economic activity of municipal territories is enhanced taking into account their potential. The range of publications discuss the specific aspects of the issue (Koroleva \& Evdokimov, 2015; Wolfschütz, 2020; Robert \& Mullinix, 2018; Zhao, Leng, Sun, \& Yuan, 2019).

The researchers of the World Economic Forum on shaping future economic progress in 2017 developed a new system for assessing the economic development of countries - Inclusive Development Index, which includes three groups of indicators (growth and development; inclusiveness; intergenerational continuity and development sustainability). In this rating, Russia's indicators have a positive trend, in 2018 it took the 19th position (World Economic Forum, 2021). However, the country`s performance in the three dimensions of the Index is not homogeneous: the processes of economic development have higher values in comparison with integration, equality between generations and sustainability. The given research is devoted to the solution of these problems. Issues of inclusive development in various contexts are also studied in the works of Russian scientists Avdokushin \& Ivanova (2014), Biryukov (2011), Pakhomov et al. (2014), Barinova \& Zemtsov (2019) and others. Inclusive development allows to manage global risks: social, environmental, geopolitical. In recent decades, the issues of sustainable development and inclusive economic growth have been in focus of study by leading international organizations.

The issue of municipal development has long been of interest to Russian scientists and experts. The most interesting investigations on this problem were carried out by such researchers as Blinova et al. (2020), Vorontsova (2021), Vorontsova et al. (2021), Zakshevsky (2021), Zakshevsky et al. (2021), Adukova et al. (2011), Bondarenko (2021), Bondarenko (2014), Kovalenko (2019), Kovalenko (2021), Merenkova (2021), Chepurnykh \& Merzlov (2017), Polushkina (2020). In particular, these works emphasize the significant differences of municipal territories compared to the urban areas.

In general, these studies indicate the negative trends in the development of many municipal districts of the country. Territorial differentiation continues to increase, real incomes of residents are declining, and the issues of rural inhabitants access to social and engineering infrastructure have not been fully resolved. This necessitates a dramatic change in the model of rural development. It should focus not only on the growth of agricultural production, but also on ensuring inclusiveness, which will reduce the level of differentiation in the social development of rural residents. The concept of inclusiveness allows to consider the municipal areas as an inherent part of the country's territory, with the comfortable living conditions and equal (compared to urban areas) adequate job opportunities, medicine, education, culture, etc. Thus, the inclusive growth is the even distribution of the benefits from economic growth among various participants in economic activity and the creation of opportunities for including as many participants as possible in the process of creating the gross municipal product. Inclusive development requires a significant improvement in the management of local resources, since the life of the rural population directly depends on the efficiency of their use (Borodova \& Prokopa, 2019).

Despite the considerable number of publications, the issues of inclusive development concerning the rural areas are not considered sufficiently. At the same time, it should be noticed that the inclusive model of the municipal districts` development ensure that the living standards of their population correspond to the level of urban residents in terms of infrastructure development and service provision.

The research object is the spatial development of the Republic of Mordovia. The region is located in the center of the European territory of Russia and is the part of the Volga Federal District. The republic is a relatively small region of the country. According to the data for 2018, in terms of territory (26.2 thousand $\mathrm{km}^{2}$ ) and population (795.5 thousand people), it occupies the 68th and 61st positions, respectively, and in terms of the population density (30.4 people per $1 \mathrm{~km}^{2}$ ) - the 34th place in Russia (Mordovia: statistic yearbook, 2019). Mordovia is the region of industrial-agrarian type: the share of industry in the gross regional product accounts for more than $30 \%$, by the number of all employed in the economy of the republic - almost $18 \%$, the share of agriculture in these indicators is 14 and $20 \%$, respectively. In recent years, growth has been observed in the main sectors of the economy, the level of innovation is high, but at the same time there is a constant decline in the number of both medium enterprises (by 14\% in 2015-2018) and 
small enterprises (by 13\%). The region is characterized by the difficult demographic situation: the population is constantly decreasing due to both natural decline and migration outflow.

The purpose of the study is to assess the indicators for 2018 characterizing the levels of economic development of municipal districts in the Republic of Mordovia. The article provides the contributions to scientific publications; it offers the assessment of the five indicators distribution by municipal districts, considers the features of economic development in the three groups of regions, presents the suggestions for the formation of the inclusive models in the municipal districts` development.

\section{Methodology and design}

The theoretical basis for the research is the concepts presented in the works of Russian and international investigators dedicated to the issues of inclusive growth and sustainable development of rural areas.

This study considers the assessment of the following five relative indicators characterizing the economic activity of the municipal districts in the Republic of Mordovia:

- gross municipal product per capita;

- population density in the territory of the municipal district;

- the share of investments in the gross municipal product;

- the number of economic entities per 10000 inhabitants;

- the share of small and medium-sized enterprises in the total number of economic entities.

Taking into account the last of these indicators seems relevant based on the significant role played by small and medium-sized enterprises in the economy of small-sized territorial entities in modern countries (Pinkovetskaia et al., 2020a; Pinkovetskaia et al., 2020b).

The initial data was the official statistical information of Mordoviastat (Mordovia: statistic yearbook, 2019), as well as the passports of municipal districts (Investments of the Republic of Modovia, 2021).

The study includes testing the following hypotheses:

- the first hypothesis - the assessment of the distribution of the municipal districts` economic activity indicators can be carried out using such mathematical models as the density function of the normal distribution;

- the second hypothesis - there are significant differences in the values of each of the five considered indicators for different municipal districts.

The research features the mathematical model of the initial empirical information. The applied models are the normal distribution density functions, their development for the estimation of relative indicators is provided in a number of articles (Pinkovetskaia et al., 2019; Pinkovetskaia et al., 2021a; Pinkovetskaia et al., 2021b). The obtained functions allow to estimate not only the average values of the indicators in the considered municipal districts, but also the values of standard deviations. It should be noted that the indicated values are used to calculate the boundaries of the ranges characterizing the values of the indicator's characteristic of the majority $(68 \%)$ of the districts. At the same time, the characteristics of the lower boundaries of the ranges in terms of indicators are equal to the difference between their mean values and standard deviations, and their sum corresponds to the upper boundary of the range.

In addition, the study provides the general scientific methods of theoretical and empirical knowledge: scientific abstraction, analysis and synthesis, analogies, comparison and groupings, the systemic method.

The cluster analysis is carried out to determine the level of differences in the economy of municipal territories in 2018. This analysis is performed on the basis of the first indicator under consideration, namely, the gross municipal product per capita. The research allows to substantiate the need to develop a strategy for the inclusive development of municipal territories. 


\section{Findings}

In the process of mathematical modeling, based on empirical data, functions $\left(y_{1}, y_{2}, y_{3}, y_{4}, y_{5}\right)$ are constructed that describe the normal distribution densities of each of the five considered indicators $\left(x_{1}, x_{2}, x_{3}, x_{4}, x_{5}\right)$ :

- $\quad$ gross municipal product per inhabitant, thousand rubles

$$
y_{1}\left(x_{1}\right)=\frac{2750.05}{153.10 \times \sqrt{2 \pi}} \cdot e^{\frac{-\left(x_{1}-261.38\right)^{2}}{2 \times 153.10 \times 153.10}}
$$

- $\quad$ population density in the territory of the municipal district, people per square kilometer

$$
y_{2}\left(x_{2}\right)=\frac{125.71}{7.64 \times \sqrt{2 \pi}} \cdot e^{\frac{-\left(x_{2}-15.80\right)^{2}}{2 \times 7.64 \times 7.64}} \text {, }
$$

- $\quad$ the share of investments in the gross municipal product, $\%$

$$
y_{3}\left(x_{3}\right)=\frac{102.67}{6.91 \times \sqrt{2 \pi}} \cdot e^{\frac{-\left(x_{3}-10.75\right)^{2}}{2 \times 6.91 \times 6.91}},
$$

- $\quad$ the number of economic entities per 10000 inhabitants

$$
y_{4}\left(x_{4}\right)=\frac{534.29}{33.46 \times \sqrt{2 \pi}} \cdot e^{\frac{-\left(x_{4}-205.12\right)^{2}}{2 \times 33.46 \times 33.46}} \text {, }
$$

- $\quad$ the share of small and medium-sized enterprises in the total number of economic entities, $\%$

$$
y_{5}\left(x_{5}\right)=\frac{102.67}{7.44 \times \sqrt{2 \pi}} \cdot e^{\frac{-\left(x_{5}-89.48\right)^{2}}{2 \times 7.44 \times 7.44}}
$$

Checking the quality of functions (1)-(5) based on the Shapiro-Wilk, Pearson and Kolmogorov-Smirnov criteria shows that all these functions provide the valid approximation of the empirical data. Thus, the first hypothesis is confirmed.

The constructed functions allow to determine the values of indicators describing economic activity in the considered municipal districts. These indicators are summarized in Table 1. The second column presents the average values for the regions; the third column provides the ranges with the values of the indicators for most of the districts. 
Table 1.

The values of indicators characterizing the entrepreneurial activity.

\begin{tabular}{lll}
\hline Indicator & $\begin{array}{l}\text { Measure of } \\
\text { average }\end{array}$ & $\begin{array}{l}\text { Values in most } \\
\text { municipal districts }\end{array}$ \\
\hline 1 & 2 & 3 \\
Gross municipal product per inhabitant, thousands of rubles & 261.38 & $108.28-414.48$ \\
$\begin{array}{l}\text { Density of population on the territory of the municipal district, person } \\
\text { per square kilometer }\end{array}$ & 15.80 & $8.15-23.45$ \\
$\begin{array}{l}\text { Equity contribution in gross municipal product, \% } \\
\text { The number of economic entities per 10000 inhabitants }\end{array}$ & 10.75 & $3.84-17.66$ \\
$\begin{array}{l}\text { Percent of small and medium enterprises in the total number of } \\
\text { economic entities, } \%\end{array}$ & 205.12 & $171.66-238.58$ \\
\hline
\end{tabular}

Source: Calculated by the authors using functions (1)-(5).

The analysis of the variation range for each of the indicators, presented in Table 1 are carried out to test the second hypothesis on the differentiation of indicators across municipal districts. The indices of variation for each of the indicators are given below:

- gross municipal product per capita - 59\%;

- population density in the territory of the municipal district - 48\%;

- the share of investments in the gross municipal product - 64\%;

- the number of economic entities per 10000 inhabitants - 16\%;

- the share of small and medium-sized enterprises in the total number of economic entities - $8 \%$.

The values of the variation indices show the presence of significant differentiation in the municipal districts of the first three indicators (variation of more than 33\%). The fourth and fifth indicators show insignificant differentiation. Consequently, the second hypothesis is partially confirmed.

At the next stage of the study, the cluster analysis is carried out to categorize the municipal districts into three groups. The first group includes six districts with a gross municipal product per inhabitant of more than 301 thousand rubles. The second group includes nine districts with a gross municipal product per inhabitant from 151 to 300 thousand rubles. The third group includes seven districts with a gross municipal product per inhabitant of up to 150 thousand rubles. Table 2 shows the indicators for these groups of districts.

Table 2.

Grouping of municipalities by economic indicators (2018)

\begin{tabular}{|c|c|c|c|c|c|}
\hline Municipal areas & $\begin{array}{l}\text { Gross } \\
\text { municipal } \\
\text { product per } \\
\text { inhabitant, } \\
\text { thousands of } \\
\text { rubles }\end{array}$ & $\begin{array}{l}\text { Density of } \\
\text { population on the } \\
\text { territory of the } \\
\text { municipal district, } \\
\text { person per square } \\
\text { kilometer }\end{array}$ & $\begin{array}{l}\text { Equity } \\
\text { contribution in } \\
\text { Gross } \\
\text { municipal } \\
\text { product, \% }\end{array}$ & $\begin{array}{l}\text { The number } \\
\text { of economic } \\
\text { entities per } \\
10000 \\
\text { inhabitants }\end{array}$ & $\begin{array}{l}\text { Percent of } \\
\text { small and } \\
\text { medium } \\
\text { enterprises in } \\
\text { the total } \\
\text { number of } \\
\text { economic } \\
\text { entities, \% }\end{array}$ \\
\hline \multicolumn{6}{|c|}{ First group of municipal districts } \\
\hline Insarskiy & 388.7 & 12.2 & 17.7 & 188 & 91.0 \\
\hline Ichalkovskiy & 417.5 & 14.1 & 11.1 & 217 & 77.4 \\
\hline Lyambirsky & 375.5 & 38.6 & 8.7 & 206 & 99.0 \\
\hline Ruzayevskiy & 470.4 & 55.6 & 1.9 & 218 & 96.3 \\
\hline Torbeyevskiy & 652.2 & 16.4 & 12.9 & 192 & 81.8 \\
\hline Chamzinskiy & 1480.7 & 29.4 & 14.8 & 219 & 98.2 \\
\hline \multicolumn{6}{|c|}{ Second group of municipal districts } \\
\hline Ardatovskiy & 151.2 & 20.6 & 7.8 & 160 & 97.5 \\
\hline Atyashevskiy & 282.6 & 15.4 & 9.8 & 217 & 91.2 \\
\hline Bolsheignatovsky & 164.6 & 8.1 & 5.1 & 203 & 95.1 \\
\hline Dubenskiy & 220.6 & 12.7 & 21.2 & 229 & 87.8 \\
\hline Kadoshkinskiy & 296.3 & 10.7 & 1.3 & 247 & 86.2 \\
\hline Kovylkinskiy & 293.6 & 18.4 & 78.1 & 206 & 97.6 \\
\hline
\end{tabular}




\begin{tabular}{lcllll}
\hline Kochkurovskiy & 264.4 & 12.0 & 6.7 & 193 & 81.9 \\
Romodanovskiy & 285.3 & 24.7 & 5.5 & 264 & 79.6 \\
Staroshaygovskiy & 192.5 & 8.1 & 6.0 & 225 & 82.7 \\
Third group of municipal districts & & & & & \\
Atyuryevskiy & 129.6 & 9.2 & 1.6 & 179 & 92.7 \\
Bolshebereznikovsky & 111.1 & 12.8 & 11.6 & 161 & 91.3 \\
Elnikovskiy & 107.1 & 9.0 & 19.2 & 201 & 91.0 \\
Zubovo-Polyansky & 101.2 & 20.0 & 23.7 & 129 & 96.9 \\
Krasnoslobodskiy & 130.3 & 16.5 & 19.1 & 224 & 96.4 \\
Temnikovskiy & 120.4 & 6.9 & 3.4 & 266 & 78.6 \\
Tengushevsky & 95.3 & 11.8 & 7.4 & 166 & 78.3 \\
\hline
\end{tabular}

Source: Calculated by the authors.

\section{Discussion}

The three groups of municipal districts, formed according to the results of cluster analysis, require a more detailed analysis. The first group contains the most economically developed municipalities of the region, the industrial territories with a considerable number of large and medium enterprises. The only exception is the Lyambirsky district with $100 \%$ of the rural population and the two largest poultry farms both in the Republic and in Russia. In addition, this area is close to the regional capital, the city of Saransk. The first group of districts contains the industries of various branches (i.e., mechanical engineering, chemical, production of construction materials, etc.). Small and medium businesses are more developed than groups 3 and 2, as evidenced by the increase in business entities over the period from 2016 to 2018 by $12 \%$ compared to $5.3 \%$ in the third group and $10.9 \%$ in the second group. Calculations showed that 176.9 thousand people live in this set of districts from them $52 \%$ are rural population.

The second group includes 9 districts with agro-industrial specialization; they are varied from having a small share of the processing industry, mainly agricultural raw materials (15-17\%), to a significant share of industry (40\%) in the Ardatovskiy district. The districts of this group comprise 9 large enterprises (including three agricultural) and 30 medium businesses. This group of districts is home to 145.6 thousand people from them $71 \%$ are rural population.

The third group includes the municipal districts with a predominantly agricultural specialization containing the share of agriculture in the gross municipal product from $54 \%$ in the Bolshebereznikovsky to $98.5 \%$ in Tengushevsky district. The exception is the Zubovo-Polyansky region, with the concentration of more than $27 \%$ of the forest area and the development of woodworking. In the municipalities of the third group, there are only 2 large enterprises, as well as 19 medium enterprises. The territories of the municipal districts of this group are inhabited by 131.1 thousand people from them almost $70 \%$ are the rural population.

As can be seen from the presented data, the rural population predominates in the municipal districts of the Republic of Mordovia. Taking this into account, proposals for the formation of inclusive models for the development of municipal districts should pay close attention to the needs of the rural population. For many years, the idea of inclusiveness, as applied to the development of territories, did not find adequate support from the state. This was largely described by the emphasis on ensuring sustainable development of industries, fields, complexes and solving environmental problems. The integrated implementation of the ideas of sustainable development was extremely difficult, and sometimes even impossible, which led to a gradual expansion of compromise approaches. One of these approaches emerged from the concept of inclusive development; it was targeted at the poorest and most vulnerable social groups (Sachs, 2004).

Inclusive development implies not only economic growth, but also the implementation of the direct democracy principles (civil, social and political rights) and the distribution of public goods (services of medical institutions, education, infrastructure, etc.) involving all members of society. According to Kosiedowski (2016), a model of economic development is inclusive if it unites society in the direction of observing human rights standards and principles; provides everyone with the opportunity to participate in social and economic life and use the effects of economic growth; ensures non-discrimination and responsibility for making and implementing decisions. The inclusive development leads to poverty reduction and provides "socially excluded" people with the opportunity to benefit from economic growth.

The idea of inclusiveness is currently being actively developed and promoted by the world's most authoritative organizations. The resolution of the 2015 UN Summit, "Transforming Our World: The 2030 
Agenda for Sustainable Development," mentions the issue of inclusion in almost all 17 adopted Sustainable Development Goals, and some of them directly use the term "inclusive".

However, the previously studied issues of ensuring inclusive development do not cover the entire range of urgent problems that are directly related to overcoming the economic, social and political isolation of the rural population. At the same time, various organizations and movements around the world have long been holding large-scale actions to draw the attention of the world community to the fact that people living and working in rural areas often become "victims" of systemic discrimination, human rights violations and various abuses. Since a considerable share of the income of farmers and other rural residents is linked to agriculture, the liberalization of agricultural trade and the globalization of agri-food markets reduce their access to resources. Many poor rural households experience significant persistent or recurrent shocks that force them to reduce consumption, sell land and property, and move to the urban areas.

To determine the major elements of the strategy for inclusive development of rural areas, it is vital to understand what changes are to be made in different directions (demography, market and social infrastructure, agricultural development) in order to ensure balanced socio-ecological and economic development.

To implement the strategy of inclusive development, the authors propose the following major directions:

- development of measures for the implementation of the national conservation policy in relation to rural areas;

- ensuring the sustainability of agri-food systems.

The first direction provides for the formation of a set of measures that could reduce migration flows from the countryside to the urban areas, ensure the development of social infrastructure and increase the standards of living in rural territories. Sociological studies confirm that almost a third of the urban adult population is ready to move to the countryside, if the necessary conditions for life are available. The important role is played by the development of social standards, which should not constitute a narrow list of minimum provisions, but be able to provoke the competition in financial resources for the development of territories. The standards are to stimulate the process of upward social and economic convergence, which could gradually provide the higher levels of social protection for the country`s citizens. The social standards should be grounded on the principles of adequacy and quality, which implies adopting the integrated approach, ensuring equal opportunity and treatment, rethinking some basic assumptions on the valid tools for employment and social protection systems, such as the specific activation policies and the hierarchies in social benefits.

In the conditions of the Russian rural territories, the implementation of the first proposed direction implies a significant role that belong to non-profit organizations (NPOs). They are of particular importance for the social development of a territory. In the developed countries, the effectiveness of NPOs' activities largely determines the level of the rural areas' development. The state program of the Russian Federation "Comprehensive development of rural areas" is currently being implemented. Until 2019, the federal target program "Sustainable development of rural areas for 2014-2020" was in effect. Certain activities of the program can also be implemented with the involvement of the non-profit sector (e.g., the subprogram "Creation and development of infrastructure in rural areas"). Almost $90 \%$ of the Russian Federation regions have developed and adopted state programs to support socially oriented NPOs. In this regard, the leading regions include the cities of Moscow and St. Petersburg (education, culture, social protection and social services, youth policy), Samara region (educational activities, social protection and social services), republic of Tatarstan (Kosygina, 2018).

The second direction should be aimed primarily at ensuring the sustainability of agricultural development, as the basis for the growth of agri-food systems and as the major branch of specialization in rural areas. At the same time, in a society focused on inclusive development, agricultural growth and incomes cannot be an end in themselves. Sustainable agricultural development is considered as a basic condition for rural communities, which creates opportunities for rural development, to achieve other important social goals, as it creates reserves to support health and the environment, education and other spheres of rural development. 
In this regard, the authors consider it critical to create a strategy for the development of the agri-food system in Russia, which will be based on the principles of sustainable development. Within the framework of the proposed strategy, it is essential to set the development goals, tools and measures to achieve them, as well as the models of the integration-balanced interaction, which ensure the balance and sustainability among the social, economic and environmental components, the financial needs and opportunities of the territories, the interests of all economic entities and the other subjects of the agrarian sphere. Such models are already studied in the work of Drobkova (2017). The models are to be based on government support aimed at stimulating production, taking into account the spatial development, comparative and competitive advantages of the individual territories of the country. The strategy for the development of the agri-food system should be coordinated with the macro-regions of the country. In turn, the state agricultural policy is to be aimed at increasing investment activity, preserving and restoring natural potential, rational use of agricultural raw materials, reducing production costs and losses, and increasing the availability of food. Building models of integration-balanced interaction implies the necessity to carry out a preliminary comprehensive analysis, including the identification of general trends in the development of the agrarian sector and the food market; determination of cause-and-effect relationships between elements of the agrifood system; assessment of the changes intensity in its structure; identification of the interests of the state, business, rural residents and consumers of food products.

Thus, in order to ensure sustainable and balanced development of the agri-food system, it is necessary to apply the methods that could affect all the system elements, contribute to the widespread introduction of agro-ecological methods, as well as strengthen the links between urban and rural areas, producers, markets and consumers; provide ecosystem services to address nutrition problems (FAO, 2021).

\section{Conclusion}

The article presents the results of studying the features of the economic development across the municipal regions in the Republic of Mordovia. The research achieves the purpose of the study, which is to assess the indicators that developed in 2018, characterizing the levels of economic development of the municipal districts. The authors contribute to the field, offering the academic novelty and originality:

1. Proposed and implemented is the methodological approach to assessing the five indicators using the density functions of the normal distribution;

2. It is shown that the values of each of the five indicators have significant differences across countries;

3. By applying cluster analysis, three groups of municipal districts are formed;

4. It is proposed to use inclusive models for the effective development of municipal districts.

Inequality in the development of municipal districts is explained by multiple factors: natural resources, geographic location, the activities of economic entities, the development of social infrastructure, the population structure and density. The analysis of the socio-economic development of the municipalities in the Republic of Mordovia provides grounds to state their significant differentiation and identify the problems requiring a change in the model of rural development with an emphasis on inclusive aspects. The concepts of economic growth in the modern world should be primarily focused on solving social, demographic and cultural problems of the countryside; more attention in strategic and program documents is to be paid to villagers; the important role should be played by the development of social standards. The stated issues justify the demand to develop a policy for the inclusive development of rural areas. Its implementation will ensure a higher level and quality of life for rural inhabitants, and, consequently, sustainability in the development of their resident areas.

The results of this work have a certain theoretical and practical significance for governments, public organizations and the population. The methodological approach presented in the article can be used to assess the features of the development of territories.

Since the authors consider the data characterizing all 22 municipal districts of Mordovia, the study does not have any limitations related to the lack of information. Further research can be associated with an assessment of the economic development of municipal districts that are part of other regions in Russia. 


\section{Bibliographic references}

Adukov, R., Adukova, A., \& Yusufov, R. (2011). Basic conditions for the development of rural areas. Bulletin of Agrarian Science, 32(5), 38-41.

Avdokushin, E., Ivanova, V. (2014). Inclusive development: main directions, basic prerequisites and possible restrictions. Questions of a new economy, 3, 4-13.

Barinova, V., \& Zemtsov, S. (2019). Inclusive growth and stability of the regions of Russia. Region: Economics and Sociology. 1, 23-46.

Blinova, T., Bylina, S., \& Rusanovsky, V. (2020). Modeling of factors affecting the decrease in mortality of the rural population of Russia. Bulletin of the Saratov State Social and Economic University, 2(81), 21-25. (In Russian)

Biryukov, A. (2011). Inclusive development in the context of global revolutions. Economic strategies, 12, 80-87.

Bondarenko, E. (2014). On the development of civil society in rural areas. Ogarev-Online, 7(21), 4, http://journal.mrsu.ru/wp-content/uploads/2014/02/Bondarenko-E.O.__statya-1.pdf.

Bondarenko, L. (2021). Rural-urban inequality in the physical accessibility of food to citizens of Russia: methodology of analysis and assessment. APK. Economics, Management, 9, 3-13, http://apkeu.ru/article/527.

Borodova, O., \& Prokopa, I. (2019). Inclusive rural development: a scientific discourse. Economy and Forecasting, 1, 67-82, https://doi.org/10.15407/econforecast2019.01.067.

Chepurnykh, N., \& Merzlov, A. (2017). Socio-economic factors in the development of rural areas. Scientific Journal NRU ITMO. Series: Economics and Environmental Management, 4, 92-101. (In Russian)

Drobkova, O. (2017). A model of mega-region management based on integration-balanced interaction: conceptual foundations. Regional Economy and Management: Electronic Scientific Journal, 2(50), 27.

FAO. (2021). Sustainable food systems for a healthy diet. https://www.fao.org/europe/event/detailevents/ru/c/1045984/.

Investments of the Republic of Modovia (2021). Municipal Districts. https://www.investrm.ru/mordovia/municipal/

Koroleva, E.N., \& Evdokimov, N.N. (2015). Roadmapping Development of Municipal Areas: From Creativity to Formalized Procedure. Mediterranean Journal of Social Sciences, 6(6S3), 456-462. https://doi.org/10.5901/mjss.2015.v6n6s3p456

Kosiedowski, W. (2016). Concept of Inclusive Development and Its Implementation in Central-Eastern Europe. Yearbook of the Institute of Central and Eastern Europe, 14(5), 67-89. http://www.iesw.lublin.pl/rocznik/articles/RIESW_1732-1395_14-5-276.pdf.

Kosygina, K.E. (2018). Topical issues of development of socially oriented non-profit organizations. Problems of Territory's Development, 3(95), 107-121, https://doi.org/10.15838/ptd.2018.3.95.7

Kovalenko, E. (2019). Problems of managing the spatial development of municipalities. Nikonov readings, 24, 342-344.

Kovalenko, E. (2021). Problems and prospects of spatial development of rural areas. Socio-economic aspects of the development of rural areas: Materials of the All-Russian (national) scientific and practical Internet conference dedicated to the 60th anniversary of the Faculty of Economics. Nizhny Novgorod. 129-132. https://nnsaa.ru/wp-content/uploads/2021/04/sborn-ehkon-publikac.pdf

Merenkova, I. (2021). Rural development: problems and solutions. Strategic regional development in new economic realities: Materials of the All-Russian online economic forum with international participation, timed to coincide with the celebration of the 55th anniversary of the Lipetsk branch of the Financial University, Tambov, 150-155. https://elibrary.ru/item.asp?id=44897259

Mordovia: statistic yearbook. (2019). Mordoviostat. Saransk. https://mrd.gks.ru/folder/25240

Pakhomova, N., Richter, K., \& Malyshkov, G. (2014). Inclusive sustainable growth: priorities, indicators, international experience, potential for alignment with the reindustrialization model. Problems of the modern economy, 3(51), 15-24.

Pinkovetskaia, I.S., Aleksandrova, N.R., \& Mingazova, O.N. (2020a). Entrepreneurship in national economics: significance and potential of development. Amazonia Investiga, 9(27), 428-435, https://doi.org/10.34069/AI/2020.27.03.47

Pinkovetskaia, I.S., Arbelaez-Campillo, D.F., Rojas-Bahamon, M.J., Novikov, S.V., \& Iniesta, D.S.V. (2020b). Social values of entrepreneurship in modern countries. Amazonia Investiga, 9(28), 6-13, https://doi.org/10.34069/AI/2020.28.04.1 
Pinkovetskaia, I., Arbelaez-Campillo, D.F., Rojas-Bahamon, M.J., Gromova, T., \& Nikitina, I. (2019). Female entrepreneurship development in the Russian Federation. Amazonia Investiga, 8(18), 111-118. https://amazoniainvestiga.info/index.php/amazonia/article/view/287

Pinkovetskaia, I., Gruznova, I., Lebedev, A., Tsybina L. (2021a). Investment Management in Early-Stage Entrepreneurship in Modern National Economies. Universal Journal of Accounting and Finance, 9(2), 245-251, https://doi.org/10.13189/ujaf.2021.090214

Pinkovetskaia, I., Nuretdinova, Y., Nuretdinov, I., \& Lipatova, N. (2021b). Mathematical modeling on the base of functions density of normal distribution. Revista de la Universidad del Zulia, 12(33), 34-49. https://doi.org/10.46925//rdluz.33.04

Polushkina, T. (2020). State regulation of the spatial development of rural areas. Bulletin of the Catherine Institute, 1 (49), 86-90.

Robert, N., \& Mullinix, K. (2018). Municipal Policy Enabling Regional Food Systems in British Columbia, Canada: Assessing Focal Areas and Gaps. Journal of Agriculture Food Systems and Community Development, 8(B), 115-132. https://doi.org/10.5304/jafscd.2018.08B.003

Sachs, I. (2004). Inclusive Development Strategy in an Era of Globalization. SSRN Electronic Journal. https://doi.org/10.2139/ssrn.908233

World Economic Forum (2021). The Inclusive Development Index 2018. Summary and Data Highlights. http://www3.weforum.org/docs/WEF_Forum_IncGrwth_2018.pdf

Vorontsova, N. (2021). State measures to support rural areas: the experience of the EU, the United States and Russia. Sustainable Development Economics, 1(45), 167-171. (In Russian)

Vorontsova, N., Merzlov, A., Mukhametzyanov, R., \& Platonovsky, N. (2021). Assessment of the attractiveness of rural areas from the point of view of internal migration of the population in Russia and the EU countries. Economy of agricultural and processing enterprises, 6, 40-47. (In Russian)

Wolfschütz, E. (2020). The Effect of Inter-municipal Cooperation on Local Business Development in German Municipalities, MAGKS Joint Discussion Paper Series in Economics, № 05-2020. PhilippsUniversity Marburg, School of Business and Economics, Marburg. https://www.econstor.eu/bitstream/10419/216645/1/05-2020_wolfschuetz.pdf

Zhao, Y., Leng, H., Sun, P., \& Yuan, Q. (2019). Application and Validation of a Municipal Administrative Area Spatial Zoning Model in Village-Town System Planning. Sustainability, 11(7), 1855. https://doi.org/10.3390/su11071855

Zakshevsky, V. (2021). Development of rural human capital and the agri-food market of the Central Black Earth Macro-region. New vectors of development of the agro-industrial complex and rural territories: materials of the national scientific-practical conference dedicated to the 90th anniversary of the institute, 8-13. (In Russian)

Zakshevsky, V., Merenkova, I., \& Makin, G. (2021). Monitoring of human capital in rural areas, taking into account spatial localization. Voronezh: Publishing house: Research Institute of Economics and Organization of the Agro-Industrial Complex of the Central Black Earth Region - affiliated branch with the Federal State Budgetary Scientific Institution "Voronezh Federal Agrarian Scientific Center named after V.V. Dokuchaev". https://elibrary.ru/item.asp?id=46453163 